\title{
Teaching Sustainability in Geoscience Field Education at Falun Mine World Heritage Site in Sweden
}

\author{
Magnus Hellqvist ${ }^{1,2}$ (D) \\ Received: 24 March 2017 / Accepted: 16 July 2019 / Published online: 14 August 2019 \\ (C) The Author(s) 2019
}

\begin{abstract}
Geoscience is relevant to issues in sustainability in many ways, for example through the aspects of earth sciences connected to the environment, climate, geohazards, energy and natural resources. There is also significant support for the use of active fieldwork experience as an effective way to teach sustainability in earth science. Some of the best sites for exploring sustainability issues in geoscience are those designated for special attention, such as geoparks, geosites, nature reserves and World Heritage Sites. Former mining areas are another type of useful locality to teach about sustainability in geosciences, as these sites usually present ample evidence of severe mining impacts on the environment and people through time. Historical mining activities can present typical examples of non-sustainable ways of working alongside modern remediation projects to manage severe environmental problems. Here, the Great Copper Mountain in Falun, central Sweden, is presented as an example of a "suitable field study site" for teaching sustainability in geoscience. This site is a former mining area, today museum and visiting resort and a designated UNESCO World Heritage Site. Mining and human activities have had a severe impact on this landscape for up to 1000 years. As a result, it is an example of a historical non-sustainable activity that is now the site of active and developed remediation work that aims for a sustainable future for both environment and people. The Falun site presents themes useful for teaching both geoscience and sustainability, and it is presented in order to demonstrate the advantages of using a site like this for teaching sustainability in earth science.
\end{abstract}

Keywords Sustainability $\cdot$ Geoscience $\cdot$ Field study $\cdot$ World heritage $\cdot$ Great Copper Mountain in Falun

\section{Introduction}

Many aspects of the earth sciences deal with questions regarding the environment and sustainable development (defined by e.g. Brundtland 1987a and United Nations 2015), and it is therefore important to raise questions on sustainable development when teaching geoscience. It is also preferable to incorporate field studies when teaching issues of sustainability. When choosing a field study site, it should be a locality that offers opportunities for a successful study on sustainability, as it connects to geoscience. The site should also be available to the geoscience community and it should be possible to utilise it to develop a range of educational and teaching prospects. This should include the

Magnus Hellqvist

magnus.hellqvist@geoveta.se

Geoveta AB, Sjöängsvägen 2, 19272 Sollentuna, Sweden

2 Department of Social and Economic Geography, Uppsala University, Box 513, SE-751 20 Uppsala, Sweden development of a pluralistic tradition of teaching (Paulus 2016; Rudsberg and Öhman 2010) where the teacher and students can explore different perceptions and interpretations around geoscience, environment and sustainability.

The advantage of discussing sustainability in the context of earth sciences is clearer when the Earth is understood holistically as a dynamic, interacting system with stabilising cycles (e.g. Orion and Fortner 2003; Orion and Ault 2007). Furthermore, earth sciences can be used as an effective tool to understand other fields of science such as physics, chemistry and biology (Orion and Libarkin 2014) as well as questions about environment and sustainability. These areas are all integrated with one another and account for some of the key complex parts of sustainable development in earth science, which also is the basis for dealing with complex problems in field-based studies of sustainability in geoscience.

When selecting field study sites for courses in earth science, there are many factors taken into site choice. These include availability, visibility, basics of knowledge and scientific tradition. Some preferable field sites are areas of special attention, such 
as geoparks, geosites, nature reserves and UNESCO World Heritage Sites. These sites are often appointed this special status because of their complex and diverse geological development. Still, many studies on these sites focus on protection, geotourism and sustainable tourism for the local community rather than education (e.g. Eder and Patzak 2004; Dowling and Newsome 2005; Hemiques et al. 2012; Farsani et al. 2012).

In society, sustainability issues usually address practical matters that include directly solving complex problems affecting daily life. In these cases, geoscientists work with practical problem-solving around the environment, climate, natural resources, natural hazard risks and sustainability. These questions are normally solved through teamwork, and therefore, it is important for geoscience students to practice teamwork and collaborative learning during their education. The active field study aspect of curriculum design favours this as a natural way of learning to collaborate (Orion and Fortner 2003) and studies have shown a positive influence of interdisciplinary experiences on student learning during their fieldwork training (Stokes and Boyle 2009). This supports active fieldwork experiences as an effective way to teach sustainability, develop an understanding of the complexity of sustainability in a diverse environment and prepare for the need for interdisciplinary professional collaboration.

Former mining areas are suitable for this type of active learning. These sites represent a formerly and historically nonsustainable activity. Today the discussion focus much on the development of sustainable mining and how this can function in different parts of mining industrial production. Some believe that sustainable mining is an inherent contradiction in its nature. This is because mining companies - in addition to mining and extraction - also use large amounts of energy and water in different parts of the production, resulting in various environmental and social impacts (The Guardian 2015). Others believe that mining and the extraction of mineral resources are in no way sustainable, but that it is still possible to work towards sustainability in some parts of the mining industry (Kenrick 2012).

The diverse view of mining acknowledges the societal need for these resources, as well as the need for sustainable mining. The clear physical impact in former, historical mining areas and lack of sustainability makes these sites useful for a broader study on issues concerning geoscience, natural resources and sustainability for the future. Older mining areas are usually exposed and available for field studies since they usually create a public interest and become the subject of preservation efforts and visit resorts. Many old and defunct mines are transformed into sites for public visits, reflecting a growing interest in industrial history, which began in the 1970s. It is noteworthy that the field of industrial archaeology, also a discipline based around these sites, was already developed in the 1950s.

The Falun Mine in central Sweden (Figs. 1 and 2) is a UNESCO World Heritage Site and exemplifies the advantages

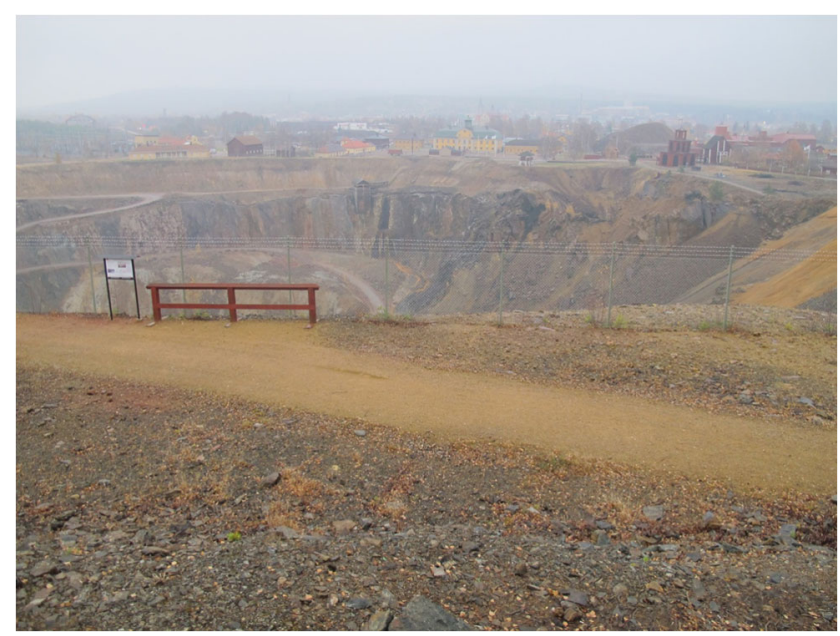

Fig. 1 The location of Falun Mine and the central part of the UNESCO World Heritage Great Copper Mountain in Falun. The view is to the east and shows the "Great Pit", which is a remnant from a mine collapse in 1687 and the later expansion of the mine up until the twentieth century. In the background are older buildings of various ages from the mining activity from the seventeenth century to the twentieth century, where there is also a local museum and a World Heritage centre. (Photo: Magnus Hellqvist)

of old mining areas as teaching sites. Here, it is used as an example for developing such field study-based teaching on geoscience and sustainability. Of today's 60 UNESCO Industrial World Heritage Sites, 24 are related to the mining industry (UNESCO 2016b). These are dominated by European sites. The number of UNESCO Industrial Heritage Sites is increasing, but on the World Heritage list in 2013, only $29(3 \%)$ of the sites were classified as industrial and technical heritage (Ringbeck 2013). Furthermore, education is an important part of the basis for a site's selection for protection and special attention by, for example UNESCO (UNESCO 2015a). Education is also a central part of sustainable development. This is presented in the Brundtland Report (1987b), and more recently, the importance of education for sustainable development is recognised in the UN Decade for Sustainable Development (2004-2015) and in the UN Sustainable Development Agenda (2030) (UNESCO 2014; UN 2019).

The field study experience in an environmental setting, such as the Falun Mine area, is an effective tool for understanding matters such as geology, landscape development, natural resources, water management, and waste management. It also conveys actions taken for remediation of such areas. In this type of study site, students can see former mining activity, its effects on the environment and active remediation work for a sustainable future.

\section{Field Studies in Geoscience}

The positive effect of incorporating field studies in geoscience education has been explored since the 1960s, showing a 
Fig. 2 Location of sites described in text. (1) Falun Mine and the town of Falun, (2) Siljan area in the county of Dalarna in central Sweden, created by a meteorite impact, (3) World Heritage High Coast and Kvarken Archipelago in east-central Sweden and westcentral Finland

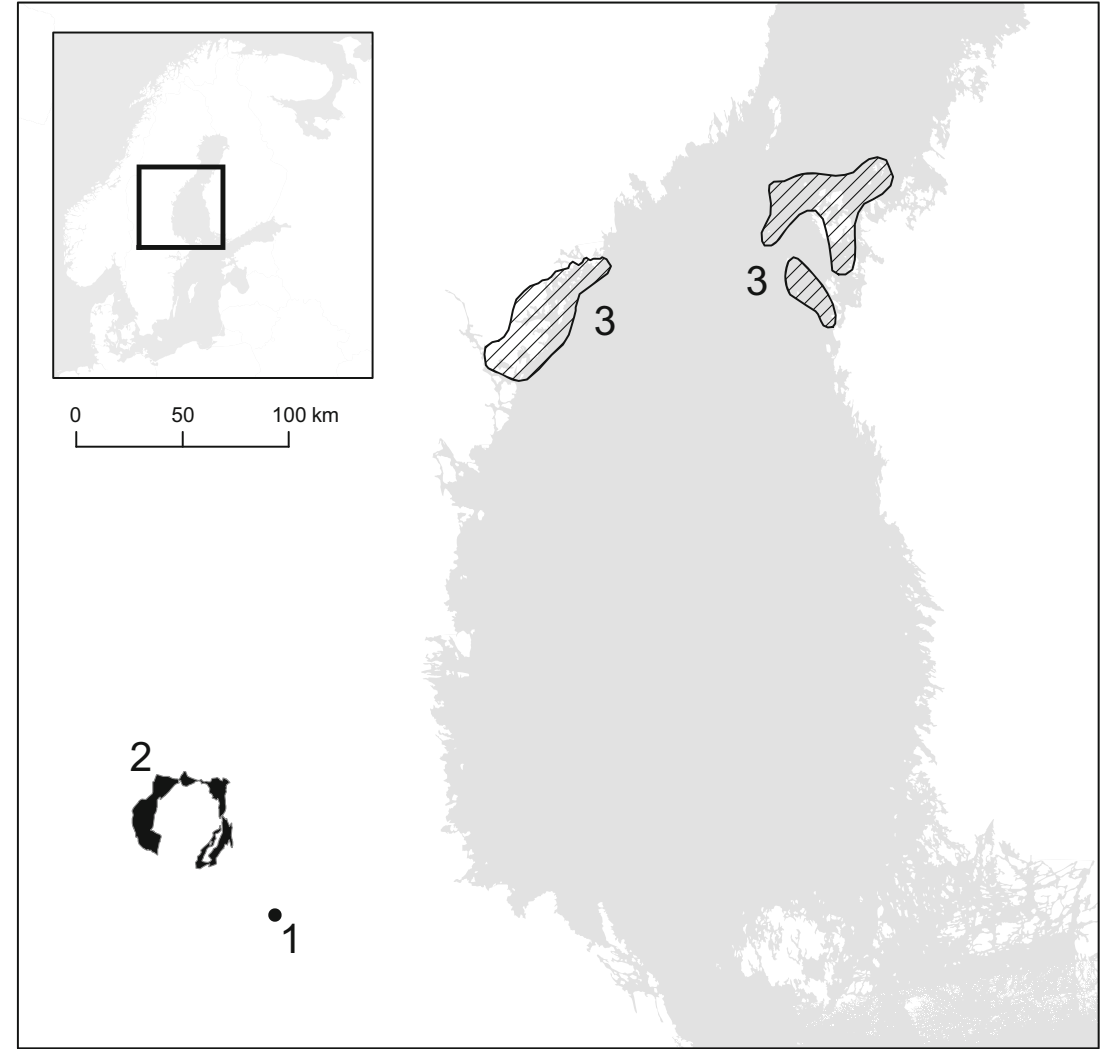

positive learning outcome of the field study experience for students (e.g. Mason 1980; Orion 1993; Orion and Hofstein 1994; Stokes and Boyle 2009). Orion (1989, 1993) raises important issues surrounding the use of field studies in geoscience education. These include that the exposure to the field object, "... has to be clear enough to speak for itself..." (Orion 1989 p. 16), and that one should conduct learning in welldefined stations that are easy to locate, together with preparatory and summary lessons that are connected to the field visit (Orion 1989, 1993). His points may be especially valid for field studies aiming to teach sustainable development and geoscience. In these cases, it might be an advantage to work in areas where the activity was non-sustainable, but where there have been actions taken to deal with the problems. Through this situation, it is possible to point to both the nonsustainable activity, as well as types of possible actions that can deal with environmental issues to reach a sustainable situation.

There are a variety of ideas behind how field studies affect the learning process and how these studies are best utilised. Some of the key ideas include the importance of preparation, the acquaintance with the site or area and limiting "novelty space" (e.g. Falk et al. 1978; Falk and Balling 1982; Orion 1989, 1993; Orion and Hofstein 1994). The idea of "novelty space" was presented by Orion and Hofstein (1994) and was divided into three main aspects: cognitive space (generally concepts and skills students deal with in field studies); geographical space (generally students' acquaintance with the physical outdoor area); and psychological space (generally the gap between students' expectations and the actual outdoor situation they face). These factors can be handled, thus decreasing the novelty space, through solid preparation before the field study.

The affective domain is important in this context. This addresses students' emotions, attitudes, and feelings, and reflects positive or negative value (Clore et al. 2001). Also, the development of attitudes and behaviours appropriate to professional practice play a fundamental role in the learning outcome. Stokes and Boyle (2009) presented work showing the effectiveness of field work in increasing the affective domain, as well as the links between positive affect and factors like confidence, motivation, and interest that have an influence on the learning outcome. Limiting the novelty space and increasing the affective domain may be important. More famous sites may be well known to students: they may be situated in familiar places (e.g. close to towns, familiar through media or central aspects of modern society). This may create erroneous expectations or link personal experiences between individual students and the place or situation, creating misconceptions of the understanding of the site.

It is important that the field study situation activates the students' minds and makes the learning process meaningful and that the learning objectives of the field observations are clear. Stokes and Boyle (2009) point to other types of gain 
from field studies, such as students' development of general as well as subject-specific skills and the importance of active student participation in education. In the case of the mining as a resource, geoscience is naturally a subject with different ways of viewing natural resources and the environment. A field visit at a former mining site creates discussions on resource management that have severe impacts and risks for the environment, even though the resource is necessary for society. The field visit at the site is therefore a driving force to raise important questions and discussion on natural resources and sustainability.

There are many studies on outdoor education for environment and sustainability issues, describing outdoor experiences and the effects of this on environmental knowledge and understanding. This is supported in a study by Paulus (2016), which discusses the advantages of a pluralistic understanding of sustainability in outdoor education practice. The author raises themes such as learning as transformation, participation and identity, and spaces. She also points to how this pluralistic understanding of the outdoor situation may promote multiple interpretations of the environment by offering a holistic experience of the landscape, in its geophysical location and specific characteristics.

Sandell and Öhman $(2010,2013)$ provide support while also raising a concern about field-based education on environment and sustainability issues. They describe how encounters with nature contribute to a nuanced debate on environment and sustainable development (Sandell and Öhman 2010). In another study (Sandell and Öhman 2013), they raise a concern about an oversimplified belief in a relationship between nature, environmental-friendly attitudes and behavioural change through outdoor learning situations. They point to factors that are also important, such as an individual's previous experience and social interactions (Sandell and Öhman 2013).

Further support for developing field-based teaching on sustainability in earth science can be found in Orion and Fortner (2003). This study describes several advantages that are associated with students' knowledge of earth system processes in the context of environmental education. The authors present a model that integrates environmental education and earth science, which is supported by examples from Israel and Cyprus (Orion and Fortner 2003). They state that it is essential for one to understand earth system processes in order to be able to understand fundamental parts of the environment and environmental problems. To accomplish this, the use of outdoor learning environments is advantageous. It is suggested that in the Falun Mine, this should be implemented through issues in the context of geoscience field education, which could make it an important part of the curriculum of a course.

Fieldwork in geoscience education also helps students to build a positive attitude towards earth science cognition. It may decrease the negative attitudes from students on broad aspects of the field, and as a result, help them link different ideas between earth and cultural systems (Orion and Libarkin 2014). It is also important to connect the theoretical side of the concepts that are explored before, during and after the field studies. This is stated in previous studies (e.g. Orion 1989, 1993) that show the importance of teaching material connected to the field study before and after the field experience itself. Different styles of teaching may help the students to detect and understand the sustainability aspect of the field experience and also provide problem-solving tools.

\section{Special Attention Sites}

Geoscience field sites of public interest include nature reserves, national parks, geoparks, World Heritage Sites and biosphere areas, among others. This special designation given to a site can also have a crucial effect on available supportive material to help develop new ways of teaching that also involve active student participation (Newbill 2009). This also offers possibilities for working with education and courses to create teaching strategies in line with the ideas from previous studies (e.g. Orion 1989, 1993; Orion and Hofstein 1994) concerning pre- and post-activities with field studies.

The best field sites for learning about sustainability issues are those that are readily available and present a diverse and interdisciplinary setting with visual components that are easy to detect. These include, for example geology, geomorphology, environment and human impact. Ideally, the site should be a product of connections between natural and cultural components, creating a diverse setting where there are connections to issues such as the environment, processes (physical, chemical) and geohazards or risk areas.

These field sites tend to have a strong connection to the local cultural history since the issue of sustainable development often connects to human impact and usage of the environment, which is useful since it provides a diverse situation for successful studies on sustainability in the field. This is assuming that this is visible during the visit and addresses not only issues on historical development (i.e. geological, archaeological and historical time) but also on issues related to present and future problem-solving.

The requirements for field sites for sustainability issues are that these sites should possess a combination of diversity, complexity and visibility. This may exclude areas where all these conditions are not fulfilled to some degree. Given these criteria, special attention sites are an educational tool for sustainability teaching. Examples of this include geomorphosites connected to natural hazards, as described by Coratza and De Waele (2012). In these cases, hazardous events leave geomorphosites with exceptional educational and cultural value. Even though the events are natural phenomena the occurrence may have been triggered by human activities, and for this reason, they connect to sustainability (Coratza and De 
Waele 2012). One typical example of that is landscape changes caused by landslides in populated areas, such as those along rivers running through populated areas. This is also directly related to future climate change adaptation.

UNESCO has several general selection criteria for Global Geoparks that in many ways fall in line with ambitions to present both geology and the environment. Education is key in UNESCO's ambitions, as their central goals include presentation and protection (Eder and Patzak 2004). For this reason, the selection of sites favours education and teaching. This is exemplified by UNESCO's Global Geoparks, which are made up of ten "focus areas" for geoparks that are directly connected to sustainability as well as education. These include among other natural resources, geological hazards, climate change, education and sustainable development (UNESCO 2016a).

There is a foundation of knowledge behind the constitution of places such as UNESCO Geoparks and World Heritage Sites. These sites are places for research, along with their aim to educate the general public about geosciences and also about environmental matters (Eder 1999; Eder and Patzak 2004; Hemiques et al. 2012). Special status sites typically have extensive background material in research and publications on different aspects of the area, and these provide support for developing course curricula. Previous studies and ample web and print resources were highlighted by Newbill (2009) as supportive material for developing new ways of teaching that incorporate national parks and also involve active student participation. These supportive materials provide a solid support for developing the complex picture that is necessary when working on tenable sustainability. It also offers possibilities for working with education and courses and creating teaching strategies in line with the ideas from previous studies (e.g. Orion 1989, 1993; Orion and Hofstein 1994) concerning pre- and post-activities with field studies.

Hemiques et al. (2012) explain how the Arouca Geopark in Portugal was used in education, based on the UNESCO vision of how to use science education - and particularly earth science education-to foster sustainable thinking, thus teaching about geology and geoconservation. The study was based on the learning structure of field studies developed by Orion (1989, 1993), and the holistic model further presented by Orion and Fortner (2003). The authors show how teaching in geoparks is a break with traditional ways of teaching, as it involves more activities integrated into the curriculum.

In Sweden, there are several field sites with diverse environments for teaching, where a variety of issues can be addressed simultaneously. One example is the Siljan area in the county of Dalarna in central Sweden (Figs. 2 and 3). This area used to be considered a potential Geosite or Geoheritage site in the future (Johansson et al. 2000) and was elected to

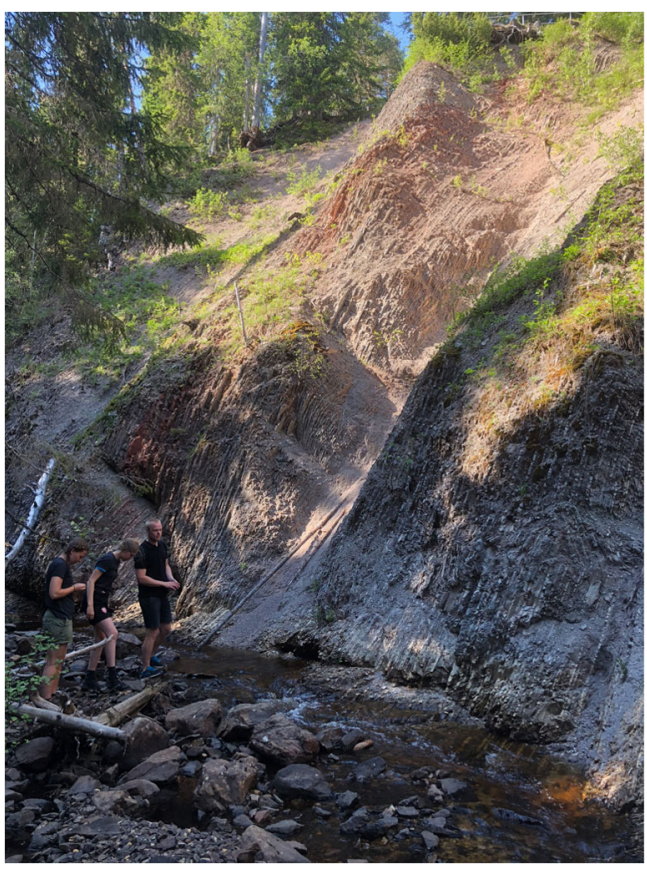

Fig. 3 Styggforsen in Siljan region, central Sweden, which was affected by a meteorite impact c. 360MA. In this site, the tipped bedrock is exposed, standing in an upright position. This was created by the impact as parts of the sedimentary bedrock moved down into deeper parts of the crater structure and were thus preserved until today. Conversely, around the former crater, the former sedimentary bedrock, together with calculated ca. $1 \mathrm{~km}$ of rock and lose material, has been removed by erosion since the time of impact

national "Geopark Siljan" by Swedish geologica survey in June 2019 (www.sgu.se). There are local and national activities working to develop the area for geotourism and local sustainable geotourism management (Meteorum 2016).

The landscape was created by a meteorite impact (c. 360MA) that created an impact structure of more than $40 \mathrm{~km}$ in diameter (Svensson 1971, 1973; Thorslund and Auton 1975; Perhans 1988) (Fig. 3). After this initial event, it was affected by external processes and finally repeated glaciations during the last 2,5MA, so only the basic parts of the impact structure are now visible. Today, the landscape at this site is very different compared to the surrounding region. This is because of the remnants of the impact structure and the fact that humans have taken advantage of the area's suitable conditions. These conditions exist because parts of the sedimentary bedrock (sandstone, limestone) were protected in the crater structure by the meteorite impact, creating more fertile soil through glaciation and other erosional processes and deposition.

The geological history is easy to detect at different individual sites in the Siljan area. At these sites, it is possible to fulfil concrete learning activities as described by Orion and Hofstein (1994). In the area, there is exposed bedrock and various geomorphological features. 
Table 1 A list of accessible study sites and objects, along with associated reference resources. Together, these create a distinguished field study site for teaching sustainability in geoscience at the Mining Area of the Great Copper Mountain (Falun Mine) in Falun, Sweden

Feature Study sites and objects Reference resources

A: Bedrock geology

B: Glaciation

(Weichsel glaciation)

\section{C: Hydrology}

D: Geochemistry, environmental impact and waste

E: Land uplift, sea level changes, environmental Wave washed material and shore changes, natural environment mineral resources in museum
Wall with bedrock formations at the large pit, where the mine collapsed in 1687

Bedrock showing chemical weathering in visitors' mine. Rock and

Geomorphological features and land cover of Quaternary deposits

Dominate Quaternary deposits from deglaciation: till, glaciofluvial material, glacial clay (not visible)

Lakes, water courses, ditches, and dam construction. Generally on higher ground.

Vast area near the mining area where the water catchment has been changed

West of mine: one lake with higher water level and changed discharge (towards mine); one human-created lake caused by damming

Ditches near the mining area

Ditches and dams found to the north and northwest of the mine and on higher ground

Local tourism track around water catchment area to the mine

Weathering colouration on the bedrock surface in the large pit

Contaminated, coloured water connected to discharge from waste products

Many large slag piles, waste rock, large and covered tailing ponds in the central large pit in the mining area

"Falun Red Paint" (weathering product from above ground waste material) discarded materials and factory remnants located close to the town of Falun

The valley formation where Falun is situated: formerly part of the Baltic Sea (bay)

Reorganised landscape, waste material, water catchment changed and increased

Changed landscape, rural landscape

Town infrastructure and waste as landfill

Evidence of historical deforestation and reforestation
Historical and recent geological descriptions and mapping (e.g. from the Swedish Geological

Survey, www.sgu.se)

Historical mining maps, primarily from the mining gallery, geological descriptions connetced to the mine activity

Historical and recent geological descriptions and mapping of Quaternary deposits (e.g. from the Swedish Geological Survey)

Mapping and information project on the water discharge from the area to the mine (www.lansstyrelsen.se/dalarna/en) Information at the Dalarna county board (www.lansstyrelsen.se/dalarna/en)

General information on mineral weathering (course textbook on earth science)

Several research projects connected to environmental issues (syntheisis in Lindeström 2002)

Project publications from FALUNproject, concerning remediation work on mining waste, published in

2010 by County Board (synthesis in Hanaæus and

Ledin 2010a)

(http://www.lansstyrelsen.se/Dalarna/Sv/Pages/default. aspx)

Projects and studies carried out by the city of Falun (www.falun.se)

Historical and recent geological descriptions and mapping (e.g. Swedish Geological Survey, www. sgu.se)

Several research projects connected to landscape development, human impact and environmental issues (e.g. Bindler and Rydberg 2015; Eriksson and Qvarfort 1996; Lundqvist 1963)

Historical record and descriptions (e.g. Lindroth 1955; Olsson 2010)

Local archive of industrial record 
Table 1 (continued)

\begin{tabular}{|c|c|c|}
\hline Feature & Study sites and objects & Reference resources \\
\hline $\begin{array}{l}\text { F: Prehistorical (pre } 1050 \mathrm{AD} \text { ) and historical } \\
\text { (post } 1050 \mathrm{AD} \text { ) human impact }\end{array}$ & $\begin{array}{l}\text { Archaeological remnants dating } \\
\text { back to at least sixth century } \\
\text { AD (County museum in Falun, } \\
\text { Falun Mine museum) } \\
\text { Landscape reorganisation through human } \\
\text { impact and settlements } \\
\text { Organisation and buildings on } \\
\text { mining area } \\
\text { Waste products at mine area } \\
\text { and in the surrounding region } \\
\text { Smaller entrances to older mine } \\
\text { galleries } \\
\text { Older buildings connected to } \\
\text { mine activity in the area }\end{array}$ & $\begin{array}{l}\text { Archaeological project reports from the Swedish } \\
\text { National Heritage Board (www.raa.se) and } \\
\text { Local Museum in Dalarna (www. } \\
\text { dalarnasmuseum.se/) } \\
\text { Several research projects connected to } \\
\text { archaeology and landscape development } \\
\text { (e.g. https://www.dalarnasmuseum.se/index. } \\
\text { php./arkeologi/rapporter) } \\
\text { Comprehensive research and publications in } \\
\text { history, literature, social science, geography } \\
\text { (e.g. Lindroth 1955; Lundqvist 1963; Olsson } \\
\text { 2010) } \\
\text { Reports on constructional and infrastructure } \\
\text { projects } \\
\text { (geotechnical reports) (Local community } \\
\text { Falun, } \\
\text { http://www.falun.se/) } \\
\text { Books and other literature on the cultural and } \\
\text { industrial history of the mine. (e.g. Lindeström } \\
\text { 2002; } \\
\text { Lindroth 1955; Olsson 2010; Rydberg 1979) } \\
\text { Resources like web sites and other media } \\
\text { available } \\
\text { on Internet }\end{array}$ \\
\hline G: Remediation & $\begin{array}{l}\text { National project for remediation } \\
\text { work (called the FALUNproject } \\
\text { in text) } \\
\text { Soil cleaning areas, rebuilt and } \\
\text { with nonvisible remnants } \\
\text { Covered and/or reorganised waste } \\
\text { Tailing pond covered with bio- } \\
\text { sludge, clay and till material } \\
\text { and with vegetation cover } \\
\text { Water cleaning plant }\end{array}$ & $\begin{array}{l}\text { Several published research projects connected to } \\
\text { environmental issues (e.g. Bindler and } \\
\text { Rydberg 2015; } \\
\text { Ek et al. 2001; Lindeström 2002; Qvarfort } \\
\text { et al. 1998) } \\
\text { Project publications from FALUNproject, } \\
\text { County Board, published in } 2010 \\
\text { (http://www.lansstyrelsen.se/Dalarna/Sv } \\
\text { /Pages/default.aspx) }\end{array}$ \\
\hline $\mathrm{H}$ : Present activity & $\begin{array}{l}\text { Visitor resort, tourism centre, } \\
\text { national cultural heritage } \\
\text { Local mining museum } \\
\text { World heritage centre and site } \\
\quad \text { (cultural property) from } 2001 \text { onwards } \\
\text { Informative signs } \\
\text { School and tourism activities }\end{array}$ & $\begin{array}{l}\text { Activity at local Falun Mine museum (guiding tours } \\
\text { in museum, area and visiting mine) } \\
\text { UNESCO World Heritage (UNESCO 2015a, b) } \\
\text { (http://whc.unesco.org/uploads/nominati } \\
\text { ons/1027.pdf) } \\
\text { Regional museum for Dalarna County } \\
\text { (www.dalarnasmuseum.se) }\end{array}$ \\
\hline
\end{tabular}

These include a landscape with many deposits from the last glaciation (Weichsel) and isostatic land uplift, as the area was previously a bay in the Baltic Sea. But the sites are distributed over a large area, demanding efficient organisation and mobility. General sustainability issues are more difficult to detect. Still, there are examples such as the remnants of earlier oil and gas prospecting as well as apparent risk situations in towns, caused by former glaciofluvial deltas and present fluvial erosion. Even so, the site presents the areas of the former impact and its exceptional geological background. The sustainability issues are also of value through local sustainable economic development through tourism, as described by Eder and Patzak (2004).
The High Coast and Kvarken Archipelago, a World Heritage site that spans from Hälsingland county in east-central Sweden through to west-central Finland, is another example of a potential high-quality field study site (High Coast World Heritage Site 2016) (Fig. 2). As a joint heritage site shared between Sweden and Finland, this area is classified as Natural Property World Heritage by UNESCO (UNESCO 2015b). In this area, there are obvious connections between bedrock geology, exogenous processes, the last glaciation and many effects of land uplift in the Baltic Sea after the last deglaciation. Differences in the bedrock present opportunities for selective erosion and there is a type of highly weathered Rapakivi granite. There are also 
several erosional remnants in the bedrock and sediments. Specifically, remnants from wave wash processes during land uplift are typical features of the area and the processes that formed them are still ongoing (Fredén et al. 2005; Fredén and Grånäs 2005). The land uplift after the retreat of the last glaciation (Weichsel) is apparent in the area, giving the area its name: the High Coast. In the future, this area of the Baltic Sea (running west-east, between Sweden and Finland) will cut off the northern Baltic Sea into a large isolated freshwater lake, caused by land uplift.

The High Coast and Kvarken Archipelago offers a diverse setting and varied geology, together with astonishing nature, but the site does not have clear exposure of the geology within a limited area (Orion 1989). This presents some challenges when it comes to organising a field study visit (Orion and Hofstein 1994) and demanding efficient mobility. Examples of sustainability are not obvious either, even though there are local and regional sustainable economic development issues caused by the local geology and nature, as described by Eder and Patzak (2004).

\section{Suitable Sustainability Field Study Site: Falun Mine}

The following is a description of the complex and diverse environment of the Falun Mine area in Dalarna County in central Sweden (Fig. 2), and its suitability as a field site for teaching sustainability. The different aspects are summarised in Table 1. This clarifies interconnections in the diverse environment, both temporally and spatially, and describes the visibility of sustainability issues together with available background information. In the following description, there are references to Table 1 to clarify the description of the different aspects and how it can build a model for teaching sustainability in geoscience in field studies.

For several reasons, historical mining was not a sustainable activity. Falun Mine closed 1992, and since then, extensive and visible action has been taken in the area for remediation and environmental protection work. The site was selected as a UNESCO World Heritage Site in 2001 (Avango and Grönlund Myrberg 2013; Olsson 2010; UNESCO 2015a, b) and is also one of the few UNESCO industrial heritage sites that refer to the notion of landscape. This is evident in the justification of the appointment, which reads ".... is the most striking feature of a landscape that illustrates the activity of copper production..." (Ringbeck 2013). Naturally, an industrial and mining landscape is greatly complex, due to the former activity. Such a site will often be geographically large, which may create problems during its nomination as a heritage site (Kloos 2013).

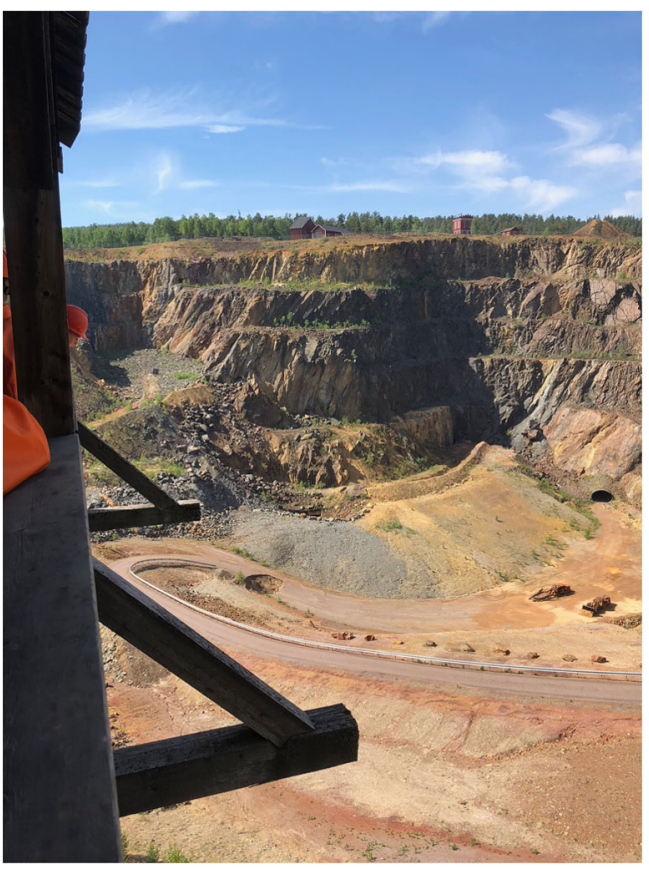

Fig. 4 During a visit in the Falun Mine area, there are several local resources to use in teaching. Much of the bedrock is exposed due to mining and a mine collapse in 1687 . Waste and other remnants are also exposed, as well as buildings from different time periods, and various mining techniques through time are evident. Additionally, activities addressing the highly toxic waste and water are seen. A field trip could include a visit to the visitors' mine, visits to older parts of the mine, and use of the local museum resources

Falun Mine is a popular tourist area, and there has been public outreach activity since the 1970s. Local resources include a "visiting mine" (Fig. 4) and a museum (Avango and Grönlund Myrberg 2013; Falun Mine 2017; Forsslund 1936; Olsson 2010; Rydberg 1979) (Table 1A, H; Fig. 4). Another value of a special attention site is the general interest among researchers. In Falun Mine, there has been considerable previous research and investigations, where the earliest studies took place in the seventeenth and eighteenth centuries (Lindroth 1955; Olsson 2010; Sahlin 1897). Dettmar (2013) define different elements of the industrial landscape, in cultural, technical and natural elements, which are summarised in Table 2. This shows the complexity of such a site and likewise supports it as a suitable field study site for teaching sustainability. This means that the site is well documented and there is a lot of available knowledge, as well as exposed features in the field (Table 1A-H). This is key for developing it into a field study site, especially relating to the diverse and complex issues concerning sustainability.

Falun Mine is in the Bergslagen region in Sweden, which is an ore-rich bedrock region in south-central Sweden where there was - and still is - significant mining activity (SNA 2011). For this reason, Falun Mine is similar to other mines in Sweden. The geology and geomorphology, as well as the local environmental issues, are visible at the site in Falun 
Table 2 Elements in the industrial and mining landscape in Falun, adapted to the Falun Mine example from Dettmar (2013), showing the advantage of using these mining site landscapes to develop models for field sites to teach sustainability in geoscience and other subjects

\begin{tabular}{|c|c|}
\hline Type of conditions & Element in the landscape \\
\hline $\begin{array}{l}\text { Directly conditioned industrial } \\
\text { sites }\end{array}$ & $\begin{array}{l}\text { - Former site for the extraction of raw } \\
\text { material/resources } \\
\text { - Former and present (Falun red paint) site for } \\
\text { production } \\
\text { - Sites for deposits_-landfills/dumps/mine spoil heaps }\end{array}$ \\
\hline $\begin{array}{l}\text { Indirectly conditioned areas which are necessary for } \\
\text { the industrial activities }\end{array}$ & $\begin{array}{l}\text { - Technical infrastructure between sites, towns, regions } \\
\text { and international } \\
\text { - Social infrastructure }\end{array}$ \\
\hline $\begin{array}{l}\text { Areas more or less influenced by industrial activities } \\
\text { other origin and uses }\end{array}$ & $\begin{array}{l}\text { - In the surrounding of the sites } \\
\text { - In larger distance to the sites }\end{array}$ \\
\hline Changes through the use of industrial produced thing & $\begin{array}{l}\text { - Consequences by products on landscape, earth and } \\
\text { human society. } \\
\text { Dettmar (2013) mention agriculture sector, traffic, } \\
\text { buildings, computer, etc. }\end{array}$ \\
\hline Industrial landscapes in Falun & $\begin{array}{l}\text { - Mining in larger dimensions ("mining landscapes") } \\
\text { - Extraction of other raw materials in smaller } \\
\text { dimensions } \\
\text { - Processing of products and semi-products in larger } \\
\text { dimensions }\end{array}$ \\
\hline $\begin{array}{l}\text { The nature of industrial landscapes - nature studies } \\
\text { perspective }\end{array}$ & $\begin{array}{l}\text { - Geological dimensions } \\
\text { - Hydrological dimensions } \\
\text { - Biological dimensions }\end{array}$ \\
\hline
\end{tabular}

(Tables $1 \mathrm{~A}-\mathrm{F}$ and 2). The environment is affected by major human impacts, including readily evident mine waste disposal and in-filling. This activity also affects places further away from the mine through pollution transported in the air and water systems, as well as heavy metals that are found in the sediment record (e.g. Bindler and Rydberg 2015; Ek and Renberg 2001; Ek et al. 2001; Renberg et al. 1994).

The basic geology of Falun Mine impacts the present situation of the site. This must be considered in order to understand the complicated environmental history and the need for remediation and actions to create a sustainable situation. The geology is complicated and inconsistent with the current understanding of geological profiles of other parts of Scandinavia. The bedrock geology and the origin of Falun Mine's ore are proposed to stem from a back-arc basin dating from 1900 million years ago (Allen et al. 1996). The bedrock subsequently went through metamorphic processes due to the tectonic movement (Koark et al. 1986; SNA 2009) (Table 1). The ore is made of a volcanically hosted massive sulphide ore deposit (VMS), a formation that is typically formed in active volcanic areas (Allen et al. 1996). The mineral and metal resources at the site are diverse. The highest production during mining was of sulphur (with a total production of $3500,000 \mathrm{t}$ ), even though the mine is most famous for its content of copper (with a total production of $400,000 \mathrm{t}$ ). The mine produced 2/3 of Europe's copper during the seventeenth century, a period that is known as the "golden age" of the mine. Still, the ore contains several other metals and elements including iron, gold, silver, zinc and lead (Lindroth 1955; Lindeström 2002; Olsson 2010).

Because of the complexity of the site, it is advantageous to perform pre-activities based on background information before the field study visit (Table $1 \mathrm{~A}-\mathrm{G}$ ). These should cover the local geological history, as this connects to basic components of bedrock formation processes. During the visit, it is also possible to explore the geology. The bedrock is visible in a large open section of an enormous pit created following a collapse in the mine in 1687 and which was later expanded during mining (Figs. 1 and 3) (Table 1A). The geology is explained in a local museum, and a connected visiting mine allows students to further explore the geologic features (Falun Mine 2017) (Table 1A, H) (Fig. 4).

The geomorphology of the landscape is readily apparent and represents a typical Swedish example. Remnants and deposits from the last glaciations, as well as postglacial deposits partly affected by isostatic land uplift (as the area was formerly part of the Baltic Sea) are visible (Table 1B, E). The site was originally a type of wetland called a mire, and there are still remnants from this in the sediment and local hydrology. The geology is important in a mine area and the development at the site is to a large extent dependent on this. Mining also impacts other natural aspects of the area, especially water resources, wood resources and available land for cultivation (Table 2). The natural setting of Falun Mine together with the cultural 
Fig. 5 The location, spatial distribution and type of deposited waste material around the Falun Mine and under the town of Falun. (Source and permission authorised from County board of Dalarna, Sweden)

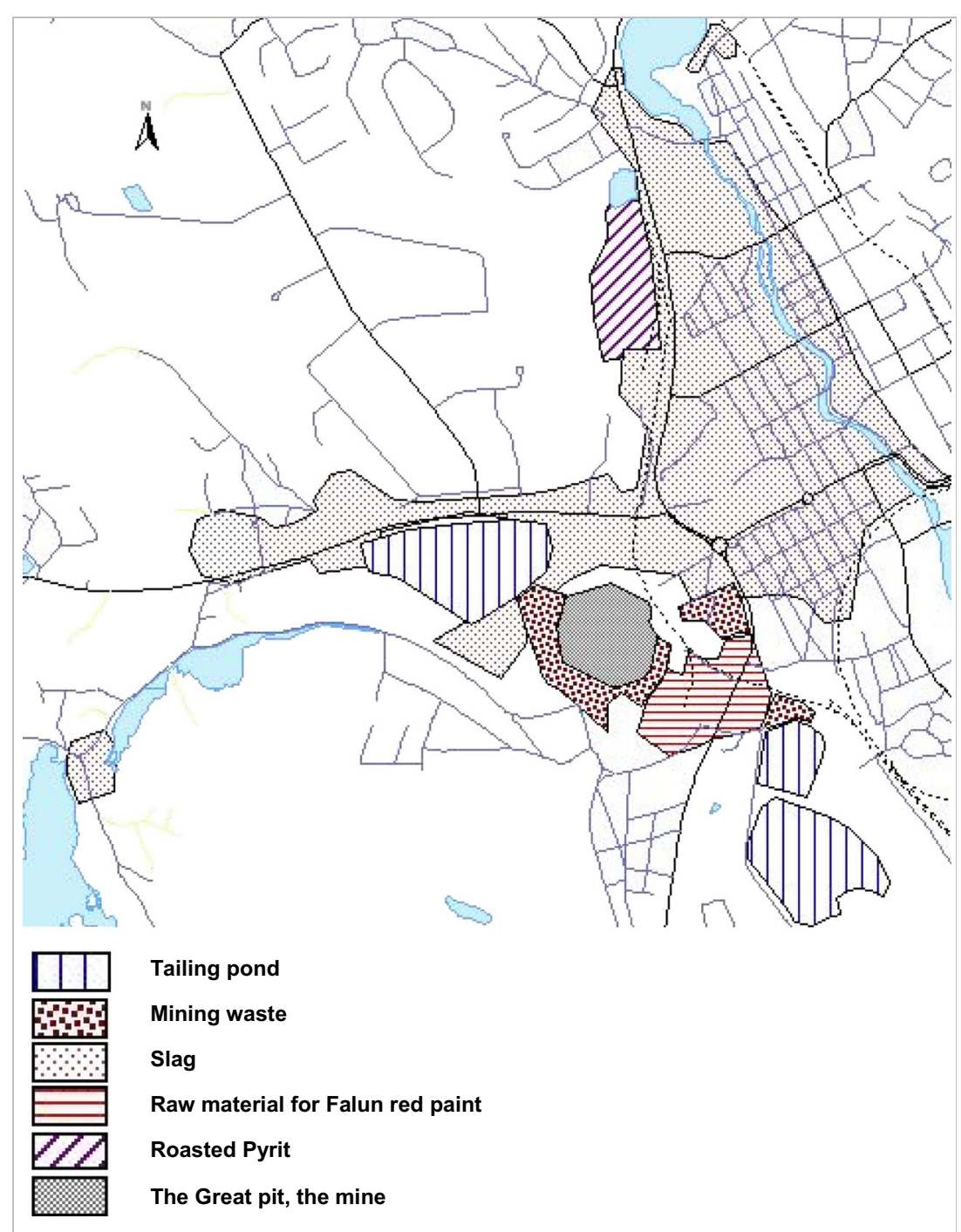

development dominate the vast landscape changes, and the human impact on the environment is clear (Hanaæus and Ledin 2010a; Lindeström 2002). The human impact is evident. In the area, one can find exposed piles of mining waste, slag, roasted pyrite, tailing ponds and raw material for "Falun red paint", described further below (Fig. 5) (Table 1D, F, G).

In the area, there are potential conflicting opinions on how to deal with environmental issues and cultural heritage interests. This not only applies to toxic waste problems but also issues such as the historical redirection of water courses from surrounding areas to the mine and the impact on nature from the high amount of heavy metals in the waste deposits (Lindeström 2002). A large portion of the area, as well as its components and remnants surrounding the site, is accessible by foot. This opens the area for arranged visits and activities within reasonable time frames (Fig. 5) (Table 1A, C-H). For these reasons, the site fulfils the profile of a complete field study site. It incorporates a complex and diverse suite of factors in a visible way and within a reasonable spatial scale for a field study, combining diversity, complexity and visibility.

There are general issues in sustainability that connect science, engineering and society in many ways (Table 2). The Falun Mine has played a central role in the local community of Falun, Sweden. Earlier in history, it was important even more broadly to Sweden as a nation, especially during the sixteenth and seventeenth centuries (Olsson 2010). As a result, there was a heavy impact on society from the growing mining community and infrastructure (Table 2). The mine was established, and the town of Falun grew up around it at a much later stage. In 1992, there was a significant change in the local community caused by the closing of the mine (Avango and Grönlund Myrberg 2013; Olsson 2010).

The geological and geochemical complexity of the site, as well as the heavy human impact, provides a situation for a variety of different types of studies and also methodologies. This creates opportunities for discussions on different 
scientific methods in both a theoretical and a practical sense. One methodological issue arising from the area is the problem of accurately dating the geology, landscape development and early mining activity. This goes together with the complicated issue of temporally identifying the steps in the area's development (Bindler and Rydberg 2015; Hellqvist 2014; Lindroth 1955; Lundqvist 1963; Olsson 2010), which was done based on carbon 14 dating and geochemical analyses of sediment layers. Until the shutdown of the mine in 1992, mining activity continued uninterrupted at the site since at least 1288 . The mining began earlier, but 1288 marks the earliest written record of activity in the mine (Lindroth 1955). Other measurements indicate that activity started up to 1000 years ago (Lundqvist 1963) and some studies claim that mining activity started up to 1300 years ago (Eriksson and Qvarfort (1996), although the validity of these studies is questioned (Bindler and Rydberg 2015). Regardless of the exact starting date, the persistence of the activity in the area has had severe impacts on the environment that are easily observed today (Hanaæus and Ledin 2010a; Lindeström 2002) (Figs. 1 and 5) (Tables 1D, F-H and 2).

One of the negative parts of the mining in Falun is the ore's content of lead, cadmium, zinc and sulphur, which are released during the industrial processing of the ore. This is important for visualising the environmental aspect of the site. The processing is complicated, especially the older methods for extracting the content of the bedrock, which released a lot of metals into the air and water. Sulphur was the largest product from the mine in terms of total mine production: there was a sulphuric plant in Falun from the middle of the nineteenth century until the 1970s. This created a significant level of air pollution during its operational period (Ek et al. 2001; Håkansson 1983; Lindeström 2002; Qvarfort et al. 1998). The geochemical and environmental situation is complicated. The sulphide ore creates a complex situation in reality, but the issue provides the basis for discussions on these problems and their solutions in theory and in the field. These issues are a way to connect the geology to industrial processes and environmental problems, which is the challenge for creating a sustainable environment.

The extraction process used on ore can have a negative effect on the surrounding environment. It is difficult to extract, for example the copper from the ore. Historically, the ore had to go through many steps - including processes of roasting at three different stages - to concentrate the copper (Lindeström 2002; Lindroth 1955; Olsson 2010). These roasting localities produced air pollution, and some of them are left in place as part of the heritage and visitor attractions and are therefore still possible to observe (Table $1 \mathrm{G}$ ). One of the major remediation projects at the site aims to carry out in situ flushing of pyrite cinder disposal sites from the former roasting sites and sulphuric acid plant, in order to manage these toxic "hot spots" (Hanaæus and Ledin 2010b; Lindeström 2002).
There are other examples of remediation work, including stabilising and covering tailing ponds (Table 1D, G, H), that visitors easily can observe.

This remediation work that addresses environmental problems and aims to create a sustainable situation is very well documented. Together with maps and reports, this is one important aspect of the mine where a discussion on the difficulties of remediation vs. preserving a place as heritage can be incorporated into the teaching curriculum. These questions are also valid for other geosites.

During the mine's active periods, its ore-roasting activities - together with many local metal-working workshops - produced by-products that had a negative impact, such as creating health problems due to the severe local air pollution (Ek et al. 2001; Lindeström 2002; Von Linnæus 2004) (Table 2). The most extensive rate of air pollution was released during the seventeenth century, measured to annually around 40,000 t (Ek et al. 2001). And still, the pollution continued through the beginning of the twentieth century. This long period of mining activity also created a huge amount of other waste products, which accumulated both in and around the mining area. This waste is exposed and obvious to visitors as pails of mine waste (Fig. 5) (Tables 1D, G and 2). Large areas of the central parts of Falun are situated on mine waste (Fig. 5), which was used as a filling material in waterlogged areas when the town was growing. This is not visible, but well documented in a vast number of archaeological reports (Dalarnas museum 2017) (Table 1F, H).

The variety of activities at the mining site created many types of waste in the area. As mentioned earlier, these include slag, slag fill, roasted pyrite (from the roasting process), modern mining tailing ponds and also weathered waste products. These weathered waste products are still used as a raw material for "Falun red paint", a traditional, and still popular, wooden house paint (Lindeström 2002) (Fig. 5; Table 1D, F, G). There are also large piles of mining waste in the form of "worthless rock piles", which are made up of parts of the bedrock that was removed during early mining activity in order to get to the minerals and metals. There are also remnants from crushing the bedrock during times when the processing was still very simple and rough.

The waste products are one of the reasons that the Falun Mine and its surroundings are considered to be a toxic place, in addition to the production of sulphur and sulphuric acid. This waste, together with waste from other mining sites in the region, contributes to heavy metal leakages into water systems through weathering, which are eventually deposited into the Baltic Sea. This provides a clear connection between the source and the main recipient for final deposition. Because of these large environmental issues in the region, and especially in Falun, there has been a regional and national concern since at least the end of the 1980s. A project to handle this, called the FALUNproject, dealt with a broad programme of 
remediation, water cleaning, waste covering and soil cleaning in the heritage site between 1992 and 2008 to provide a more sustainable environmental situation (synthesis in Hanaæus and Ledin 2010a).

Given the features presented above, Falun Mine can present a clear and understandable connection for in-field teaching and education. It shows connections between natural resources, weathering, hydrology, water catchment areas and environment, and the geochemical situation is easily followed (Table 1C-E, G). The mine's impact on the local water situation is also visible, as there are areas that are exposed and easily observable from ditches, lakes and dams close to the mine (Lindeström 2002) (Fig. 5). The presence of air pollution from the Bergslagen region is evident in sedimentation in lakes and has been detected through chemical analysis over $130 \mathrm{~km}$ from the site (Renberg et al. 1994).

Even though it is not possible to visually detect chemical weathering in the ground, results from this process are visible in several places. Visual components include the rock and lose materials on the ground, the outflow of groundwater, the water dispatched from waste piles (e.g. tailing ponds (Fig. 5)) and the precipitation of metals (especially iron) that are easy to observe. By combining course curricula and the vast number of publications on the geochemical and environmental situation in Falun together with these processes in visible areas in the field, it is possible to design separate parts of a field study curriculum to address these matters. For example, the curriculum could be developed to follow a geochemical trail, in line with chemical trails as described by Borrows (1984, 2004, 2006). Another effect of the heavy mining impact was changes to the soil, organisms and plants that were affected by mining activities (Lindeström 2002). Today, a result of this is that the soil is redistributed, covered, mixed and/or toxic in many places.

In addition to the geochemical changes, the impact of the mine also includes a number of aspects of historical daily life. These include growing settlement in the area, increased deforestation for charcoal production, redirecting water and lake courses to the mine to serve as energy resources and the trading of goods, such as the food supply on land and water. The mine was also important for the invention of technical industry devices and machines, with inventors at the site, including Christopher Polhem (late seventeenth century to early eighteenth century). This points to how mines act as catalysts for other changes in society (Olsson 2010). This is also an important point in education about the site: problem-solving in complex environments can lead to new solutions valid for other actors, and this can also create sustainable management.

Historical records and archives also present opportunities for the study of science history (Lindroth 1955; Olsson 2010). Examples of this are early visits to the site by scientists including J. F. Leopold in 1708 (Sahlin 1897) and C. Linnaeus on his trip to Dalarna in 1734 (Von Linnæus 2004). Leopold describes how he is "hit by terror" when getting closer to Falun and Linnaeus called the place "hell on earth" and described the "terrible" situation from the mining activity.

These mining activities run simultaneously with the development of settlements, infrastructure and local and national economy. Later, they are incorporated through work on remediation with advanced systems for dealing with waste products. Together, this situation can be used to follow the idea of relating the complex situation through education in a pluralistic way, as described by Paulus (2016). The activities around a mine-before, during and after-also professionally engage geoscientists to a large extent. They must deal with issues relating to prospecting and natural resource management, as well as the environment and sustainability.

The major advantage of selecting sites as defined above for teaching is that they give opportunities for repeated visits during a student's education. This can be done throughout different courses, with progression in education. The site can also be used for thesis projects and to integrate research in earth sciences into the course curriculum.

\section{Conclusion}

Former mining areas are well suited for providing a complete teaching site for geoscience, as they are pure geoscience areas that also stand as examples of human impact, environmental issues, sustainability and cultural history (Table 2 ). The issues that can be explored extend into a variety of other subjects as well, such as social science, human geography, economic history and anthropology. Fundamentally, mines are geological formations - bedrock with ore of economic value and importance for society - mined in various ways. The activities have a heavy impact on the environment, resulting in vast landscape changes that change the area from a natural situation to a human-impacted environment. The different activities in and around the mine create large volumes of waste products that need to be treated carefully.

Finally, the use of the Falun Mine area as an example of a field study site for teaching sustainability in geoscience opens up many different opportunities in teaching. The situation at a site like this might seem evocative and obvious, but this is necessary when working with these issues in teaching situations. Other examples may not be as clear when it comes to environmental issues. It is important that students get useful tools to understand the complexity of sustainability in their education: this can be applied in their future professional work.

Acknowledgements The author would like to thank Åsa Frisk for valuable comments on the original draft and to Allison Perrigo for invaluable help with English proofreading. The author is very grateful to an 
anonymous reviewer for valuable comments on the original manuscript. The author is also very grateful for the continuous opportunity to work in corporation with Falun Mine and Museum and the Falun Mine Foundation and all the fruitful discussions and help from the staff at the museum. Many ideas have been growing through teaching activities in the area and fruitful and inspiring discussions and project work by earth science students at Department of Earth Science, Uppsala University.

Funding Information Open access funding provided by Uppsala University.

Open Access This article is distributed under the terms of the Creative Commons Attribution 4.0 International License (http:// creativecommons.org/licenses/by/4.0/), which permits unrestricted use, distribution, and reproduction in any medium, provided you give appropriate credit to the original author(s) and the source, provide a link to the Creative Commons license, and indicate if changes were made.

\section{References}

Allen RL, Lundström I, Ripa M, Christofferson H (1996) Facies analysis of a $1.9 \mathrm{Ga}$, Continental margin, back-arc, felsic caldera province with diverse $\mathrm{Zn}-\mathrm{Pb}-\mathrm{Ag}-(\mathrm{Cu}-\mathrm{Au})$ sulfide and $\mathrm{Fe}$ oxide deposits, Bergslagen region, Sweden. Econ Geol 91:979-1008

Avango D, Grönlund Myrberg L (2013) Falun copper mine - industrial heritage in mining futures. In: Albrecht A, Hansell F (eds) Industrial and mining landscapes within World Heritage Context, international workshop, TU Bergakademie Freiberg/Germany, 25th October 2013

Bindler R, Rydberg J (2015) Revisiting key sedimentary archives yields evidence of a rapid onset of mining in the mid-13th century at the Great Copper Mountain, Falun, Sweden. Archaeometry. https://doi. org/10.1111/arcm.12192

Borrows P (1984) The Pimlico chemistry trail. Sch Sci Rev 66(235):221233

Borrows P (2004) Chemistry trails. In: Braund M, Reiss M (eds) Learning science outside the classroom. Routledge, Oxon

Borrows P (2006) Chemistry outdoor. Sch Sci Rev 87:23-31

Brundtland GH (1987a) Report of the world commission on environment and development: our common future. The United Nations World Commission on Environment and Development (WCED), New York

Brundtland GH (1987b) Our common future - call for action. Environ Conserv 14:291-294

Clore GL, Wyer RS, Dienes B, Gasper K, Gohm C, Isbell L (2001) Affective feelings as feedback: some cognitive consequences. In: Martin LL, Clore GL (eds) Theories of mood and cognition. Lawrence Erlbaum Associates, Mahwah, pp 27-62

Coratza P, De Waele J (2012) Geomorphosites and natural hazards: teaching the importance of geomorphology in society. Geoheritage 4: 195-203

Dalarnas museum (2017) Welcome to Dalarnas museum (Archaeology). www.dalarnasmuseum.se. Accessed 30.01. 2017

Dettmar J (2013) Industrial landscapes - approaches to a definition and a typology. In: Albrecht A, Hansell F (eds) Industrial and mining landscapes within world heritage context, international workshop, TU Bergakademie Freiberg/Germany, 25th October 2013

Dowling R, Newsome D (2005) Geotourism. Routledge, Oxon

Eder FW (1999) "UNESCO GEOPARKS" - a new initiative for protection and sustainable development of the Earth's heritage. Neues Jahrb Geol Palaontol Abh 214:353-358
Eder FW, Patzak M (2004) Geoparks - geological attractions: a tool for public education, recreation and sustainable economic development. Episodes 27(3):162-164

Ek AS, Renberg I (2001) Heavy metal pollution and lake acidity changes caused by one thousand years of copper mining in Falun, central Sweden. J Paleolimnol 26:89-107

Ek AS, Löfgren S, Bergholm J, Qvarfort U (2001) Environmental effects of one thousand years of copper production at Falun, central Sweden. Ambio 30(2):96-103

Eriksson J-A, Qvarfort U (1996) Age determination of the Falun Copper Mine by $14 \mathrm{C}$ datings and palynology. GFF 118:43-47

Falk JH, Balling JD (1982) The field trip milieu: Learning and behavior as a function of contextual events. J Educ Res 76:22-28

Falk JH, Martin WW, Balling JD (1978) The novel field-trip phenomenon: adjustment to novel settings interferes with task learning. J Res Sci Teach 15:127-134

Falun mine (2017) Welcome to Falun Mine. http://www.falugruva.se. Accessed 30.01.2017

Farsani NT, Coelho C, Costa C, Neto de Carvalho C (2012) Geoparks and Geotourism - new approaches to sustainability for the 21st century. Brown Walker Pres, Boca Raton

Forsslund KE (1936) Falu gruva och Stora Kopparbergs bergslag. En krönika

Fredén C, Grånäs K (2005) Geoturistkartan Skuleberget och Skuleskogen. Sveriges geologiska undersökning K2 (Swedish Geological Survey)

Fredén C, Grånäs K, Svedlund J-O (2005) Geoturistkartan Höga Kusten med Ulvöarna. Sveriges geologiska undersökning K1 (Swedish Geological Survey)

Håkansson L (1983) Metaller i fisk och sediment i sjön Runn och några omgivande sjöar. Delprojekt 24. Unpublished work document from Swedish EPA, Water Laboratory, Uppsala

Hanaæus Å, Ledin B (2010a) Efterbehandling av gruvavfall i Falun 1992-2008. Sammanfattande slutrapport för Faluprojektet. ("Remediation of mining waste in Falun 1992-2008. Summary report för Faluproject”, author's translation). Naturvårdsverket, Rapport 6398

Hanaæus Å, Ledin B (2010b) In situ tvättning av kisbränderdeponin i Falun. Åtgärder vid f.d. svavelsyrafabriken. (Flushing in situ of former Pyrite Cinder Disposal Site from the old sulphuric acid plant). Naturvårdsverket, Rapport 6400

Hellqvist M (2014) Falu gruva och den tidiga miljöhistorien. ("Falu mine and the early environmental history", author's translation). Dalarna 2014. Årsbok för Dalarnas Hembygdsförbund, Falun

Hemiques MH, Tomaz C, Alven Sá A (2012) The Auroca Geopark (Portugal) as an educational resource: a case study. Episodes 35: 481-488

High coast world heritage site (2016) The high coast World Heritage Site. http://varldsarveghogakusten.se/in-english/. Accessed 14.05.2016

Johansson CE (ed.), Alapassi M, Andersen S, Erikstad L, Geirsson K, Jansson A, Suominen V (2000) Geodiversitet i Nordisk naturvård ("Geodiversity in Nordic nature conservation", author's translation). Nord 200:8. Nordiska ministerrådet, Copenhagen

Kenrick V (2012) Sustainability in mining models. World PUMPS 2012: 44-47

Kloos M (2013) Landscapes in world heritage context. In: Albrecht A, Hansell $\mathrm{F}$ (eds) Industrial and mining landscapes within world heritage context, International Workshop, TU Bergakademie Freiberg/ Germany, 25th October 2013

Koark H, Kresten P, Laufeld S, Sandwall J (1986) Falu gruvas geologi. ("The geology of Falu mine", authors translation). Swedish Geological Survey (SGU), Uppsala

Lindeström L (2002) The environmental history of the Falun Mine. Stiftelsen Stora Kopparberget \& ÅF- Miljöforskargruppen AB, Falun 
Lindroth S (1955) Gruvbrytning och kopparhantering vid Stora Kopparberget intill 1800-talets början: Del I. Gruvan och gruvbrytningen. ("Mining and processing copper at Falun mine until beginning of 19th century: part I. The mine and the mining", author's translation). Skrifter utgivna av Stora Kopparbergs Bergslags $\mathrm{AB}$, Falun

Lundqvist G (1963) Falu gruvas ålder i geologisk och arkeologisk belysning. ("The age of the Falu mine based on geological and archaeological research", author's translation). Stora Kopparbergs Bergslags Aktiebolag, Falun

Mason JL (1980) Annotated bibliography of field trip research. Sch Sci Math 80:155-166

Meteorum (2016) Meteorum - touch of the universe. http://meteorum.se/. Accessed 07.04.2016

Newbill PL (2009) Using national parks to transform physical geology into an inquiry experience. J Geosci Educ 57:41-47

Olsson DS (2010) The Falun Mine. Stiftelsen Stora Kopparberget, Falun

Orion N (1989) Development of a high-school geology course based on field trips. J Geosci Educ 37:13-17

Orion N (1993) A model for the development and implication of field trips as an integral part of the science Curriculum. Sch Sci Math 93: 325-331

Orion N, Ault CR (2007) Learning earth science. In: Abell S, Lederman NG (eds) Handbook of research on science education. Lawrence Erlbaum Associates, Mahwah, pp 653-688

Orion N, Fortner RW (2003) Mediterranean models for integrating environmental education and earth science through Earth System Education. Mediterr J Educ Stud 8:97-111

Orion N, Hofstein A (1994) Factors that influence learning during a scientific field trip in a natural environment. J Res Sci Teach 31: $1097-1119$

Orion N, Libarkin J (2014) Earth system science education. In: Lederman NG, Abell SK (eds) Handbook of research on science education. Traylor and Francis, Routledge, pp 481-496

Paulus SC (2016) Exploring a pluralist understanding of learning for sustainability and its implications for outdoor education practice. $\mathrm{J}$ Adv Educ Outdoor Learn 16:117-130

Perhans K-E (1988) Berg och jord i Siljansringen: Del 1. Berg och Bergsbruk. ("Bedrock and Quaternary deposits around Siljansringen: part 1. Bedrock and mining", author's translation). Studiematerial i naturgeografi. Stockholm University, Stockholm

Qvarfort U, Löfgren S, Bergholm J (1998) Faluns historiska svavelbelastning. Reports on sulphuhr and $\mathrm{pH}$ values in the Falun area for Falun Municipality, MH, 1998:5

Renberg I, Wik Persson M, Emteryd O (1994) Pre-industrial atmospheric lead Contamination detected in Swedish lake sediments. Nature 368:323-326

Ringbeck B (2013) Industrial and mining landscapes within World Heritage Context. In: Albrecht A, Hansell F (eds) Industrial and mining landscapes within World Heritage Context, International Workshop, TU Bergakademie Freiberg/Germany, 25th October 2013

Rudsberg K, Öhman J (2010) Pluralism in practice - experiences from Swedish Evaluation, school development and research. Environ Educ Res 16:95-111
Rydberg S (1979) 1000 years of mining activity. Stora Koparberg 1979, Västerås

Sahlin C (1897) Stora Kopparberget och Falu stad i reseskildringar. ("Great Copper Mountain and Falun town in travel books", author's translation) Falu nya boktryckeri AB, Falun

Sandell K, Öhman J (2010) Educational potentials of encounters with nature: reflections from a Swedish outdoor perspective. Environ Educ Res 16:113-132

Sandell K, Öhman J (2013) An educational tool for outdoor education and environmental concern. J Adv Educ Outdoor Learn 13:36-55

SNA (2009) Geology of Sweden. National Atlas of Sweden

SNA (2011) Swedish mining and metalworking - past and present. National Atlas of Sweden

Stokes A, Boyle AP (2009) The undergraduate geoscience fieldwork experience: influencing factors and implications for learning. The Geological Society of America, Special Paper 461, pp 291-311

Svensson NB (1971) Probable meteorite impact crater in central Sweden. Nature Phys Sci 229:90-92

Svensson NB (1973) Shatter cones from the Siljan structure, Central Sweden. Geol Fören Stockh Förhande 95:139-143

The Guardian (2015). Sustainable mining: an inherent contradiction in terms? https://www.theguardian.com/sustainable-business/2015/ jan/05/sustainable-mining-business-poverty-environment-newframework

Thorslund P, Auton C (1975) Evidence of meteorite impact in the Siljan structure, Central Sweden. Bulletin of the Geological Institutions

UNESCO (2014) Roadmap for implementing the global action programme on education for sustainable Development. http://unesdoc. unesco.org/images/0023/002305/230514e.pdf. Accessed 30.01. 2017

UNESCO (2015a) Operational guidelines for the implementation of the world heritage convention. United Nations Educational, Scientific and Cultural Organisation. Intergovernmental Committee for the Protection of the World Cultural and Natural Heritage. World Heritage Centre. http://whc.unesco.org/en/guidelines/. Accessed 30.01 .2017

UNESCO (2015b) The World Geritage. The definitive guide to all 1007 World Heritage sites. UNESCO Publishing. HarperCollins Publishers Ltd. Paris.

UNESCO (2016a) Natural science, environment, earth sciences, top 10 focus areas of UNESCO global geoparks. http:/www.unesco.org/ new/en/natural-sciences/environment/earth-sciences/unesco-globalgeoparks/top-10-focus-areas/. Accessed 29 Mar 2016

UNESCO (2016b) UNESCO honours Europe's industrial legacy. http:// www.euractiv.com/section/development-policy/news/unescohonours-europe-s-industrial-legacy/. Accessed 12.05.2016

United Nations (2015) Transforming our world: the 2030 agenda for sustainable development. https://sustainabledevelopment.un.org/ post2015/transformingourworld. Accessed 30.01.2017

United Nations (2019) The sustainable development agenda. 17 goals to transform our world. https://www.un.org/sustainabledevelopment/ development-agenda/. Accessed 02.06.2019

Von Linnæus C (2004) Carl von Linnés Dalaresa 1734 (“Charles von Linnæus Dalarna travel", author's translation). Natur och Kultur, Stockholm 